\title{
Modernisation of Public Sector Financial Reporting Systems in Europe - Challenges and Milestones
}

\author{
Michal Svoboda*
}

\begin{abstract}
:
Many European countries have been carried out a modernization projects in public sector financial reporting since the last two decades. Consequence of a stronger demand for complex, reliable and relevant economic information on government is governments' efforts towards better accountability. IPSAS standards, a full accrual national financial reporting standards closed to, or national standards with clear reference to IPSAS, are often considered as the best tool for that. This article aims to identify key challenges and milestones - four key aspects of these public sector financial reporting modernization projects. It offers a comparison amongst several European countries comparing the ways these countries decided to deal with those challenges and milestones.
\end{abstract}

Key words: Governmental Accounting; Public Sector; IPSAS; IFRS.

JEL classification: H83, M41, M42, M48.

\section{Introduction}

Since the last five to ten years, discussions on modernization and reforming public sector financial reporting system in various countries has been started. In the author's opinion, two key factors have been the cause. Firstly, the International Public Sector Accounting Standards Board (IPSASB) have rapidly speed up issuing brand new public sector financial reporting standards (IPSAS standards) covering the most important financial issues going on in governments. Secondly, during the same years, a global financial crisis revealed its effects including significant negative impacts on governments' incomes. Some of these governments, both central and local, have suffered a real fiscal crisis as a consequence of financial markets' downturns. Then brand new IPSAS standards, the only set of financial reporting standards sewn for public sector entities all around the globe so far, could seem as the best answer. To conclude that or to reject this idea, comprehensive analyses are necessary to get a really reliable overview. This paper offers a comparative analysis of some different financial

\footnotetext{
Michal Svoboda; University of Economics, Prague, Financial Accounting and Auditing, Faculty of Finance and Accounting, Winston Churchill Square 4, 13067 Prague 3, Czech Republic, <michal.svoboda@vse.cz>.

The article is processed as an output of a research project Relevance účetnich informaci na konsolidovaném základu v podnikatelském i veřejném sektoru (Value Relevance of Accounting Information on Consolidated Basis in Business and Public Sector) registered by the Internal Grant Agency of University of Economics in Prague under the registration number F1/47/2015.
} 
Svoboda, M.: $\quad$ Modernisation of Public Sector Financial Reporting Systems in Europe - Challenges and Milestones.

reporting systems to enhance discussion in this field and to provide valuable basis for any future conclusion on government accounting modernization projects no matter if they are a response to the global financial crisis or/and just reaction to the new economic information users' demand. Its aim is to identify and assess key aspects that have played the role during public sector financial reporting modernization projects and have been seen as crucial for the success of these projects.

The necessary first two steps must be the definition of the aims of the public sector entities and the scope (or size) of the public sector itself. Without having identified the purpose and goals of public sector we cannot assess suitability of any financial reporting system. The aim of each of them has to be disclosure of true and fair view of financial situation and financial performance to reveal resources and capacity of each public sector entity to fulfil its future tasks, goals and responsibilities. In case of the private sector entity - a business corporation, its main purpose is typically a maximization of the company's value for owners in the short run or in the long run. Whilst the public sector company's primary aim is to provide services to its consumers, not to generate profit or increase its value (Schumesch et al., 2015). Also the Conceptual Framework for International Public Sector Accounting Standards stands clear: "Governments and other public sector entities raise resources from taxpayers, donors, lenders and other resource providers for use in the provision of services to citizens and other service recipients. These entities are accountable for their management and use of resources to those that provide them with resources, and to those that depend on them to use those resources to deliver necessary services. Those that provide the resources and receive, or expect to receive, the services also require information as input for decision-making purposes." (IFAC, 2014) Also the public sector theory supports this definition. Musgrave et al. (1994) describe the public good (contrary to the public good) as a good providing utility for all consumers, not only for those who paid for. There are others who offer basic qualities of these public goods like non-excludability and non-rivalry (Stiglitz, 2000). The economic theory then defines three main functions of the governments mostly responsible for providing these public goods (Niskanen, 1996):

- allocation,

- redistribution and

- stabilization.

Obviously we can see a clear link between general definition of public goods and the functions of the government in terms of economic theory, especially the allocation function of the government, and the identification of the purpose of public sector entities (governments) from the financial reporting point of view. 
This knowledge also helps with the second step - scope of the public sector. If we look for financial reporting systems to compare them, it is necessary to define the size of the government and to set up some qualities which need to be fulfilled by an entity to involve it to the public sector. This means we have to encompass all the entities providing public goods to their consumers especially as a consequence of their allocation function. And that would be different from state to state around the globe. There will always be borderline entities with no explicit position. We can find many examples, for instance: formally a private company with majority share of the region government assuring inhabitants transportation within some region. It mostly means connection between small villages to allow inhabitants the access to the other public services in the region like education or health care. But the same company also runs a connection between two largest cities in the region. Because of a strong demand for this connection, its price ensures for the company full cost coverage and also some profit. We could then see that this transportation service is not a purely public good, we have to distinguish between two modifications of this service, provided by the same company. The question could be whether this company is a part of public sector (hence a part of government) or a part of private sector. The IPSAS Conceptual Framework names these companies as the Government Business Enterprise (IFAC, 2014). Borderline entities represent a boundary between public and private sector that is why the qualities for their identification are crucial for definition of the scope of the public sector and thus the entities covered by the same financial reporting (accounting) rules. In case of any comparison of these systems, the scope of each set of rules would be one of the most important criteria. Other issue is to distinguish between a public sector company and a private sector non-profit (or not-for-profit) organization such as foundations, churches, political parties, unions or associations. From the principle point of view, these subjects are often embodied into the private sector (Niskanen, 1996). As for the private sector, in the perfect competition model there is a presumption of a zero profit at aggregated level. Whilst for the private non-profit sector, there is a tendency towards a zero profit at the micro level. For the public sector companies (governments), the profit is not a criterion. That means we can exclude private non-profit organisations from this analysis.

\section{Data and Methodology}

This paper uses a comparative analysis approach. There are some resources that carry out such an analysis using either a qualitative approach or using a quantitative approach. To judge specific public sector financial reporting system in some country using only quantitative criteria could mislead to incorrect or inaccurate conclusions. On the other hand, comparing these systems using only a 
Svoboda, M.: $\quad$ Modernisation of Public Sector Financial Reporting Systems in Europe - Challenges and Milestones.

basic description would be vague. That is why this paper combines various data resources using both these approaches.

Key data resources are previously available public data, information and analyses of various authorities. These could be both dependent and independent from the specific country involved in this comparison. The most volume of disposable data resources is being provided by developed countries. The most economically developed countries are associated for instance under the Organisation for Economic Co-operation and Development (OECD) which also produces many data resources even on financial reporting issues. As the OECD could be seen as an independent body, the most relevant data for this paper have been collected from its primary database. Some other comparative data have been provided also by the study of PwC company (PwC, 2014). There are also other data resources used like official civil servants' presentations which have been used where the other primary data resources were not available. Not all the financial reporting systems and not all the OECD countries or EU countries are involved.

When a comparison of different financial reporting models is being made, then probably the most reliable method for a comparison is to use the accounting base as a benchmark. Two extreme qualities of any financial reporting system have been defined: full accrual base and full cash base. Full cash based system means reporting the cash transactions only. No country-specific example is necessary to illustrate this extreme. It is an elementary, simple and technically unsophisticated approach. For the other extreme, IPSAS standards as an IFRS-based set of financial reporting rules have been chosen. At least in Europe, many governments consider IPSAS standards as a source for modernization their own systems and see their modernization efforts towards IPSAS standards as a kind of natural development (PwC, 2014, pp. 3).

The comparison has been made on two levels. At the first level, financial reporting systems in public sectors of most European countries have been compared with IPSAS/IFRS standards. That should contrast the difference and the distance from these two sets of standards as for specific country. After that, second level of comparison has been provided by choosing several European countries their public sector financial reporting system is closed to IPSAS/IFRS as a consequence of modernization projects completed in last approximately twenty years. The aim is to assess relevance of these four aspects that have been apparently important during these financial reporting reforms in all these countries and to find out if some of them have been common for all of them as a kind of common denominator ensuring success of particular modernization project. Four aspects have been identified upon research of available information sources, especially OECD databases (OECD, 2015) and PwC study (PwC, 2014): 
- using of internal or external human resources,

- inclusion or exclusion of local governments,

- the strict goal of implementation of IPSAS standards and

- implementation of new ERP systems.

Usage of internal experts (civil servants) could be cheaper and ensure firm project management, while the external consultants could mostly offer broader experience and more flexibility. In many of European countries local governments enjoy a broad independence from the central government, including the possibility of their own financial reporting rules. Aiming at local governments as a part of modernization project could result in fail of the whole project. For its success are then local governments often outside its scope. If the strict and primary aim of some modernization project is the implementation of IPSAS standards, it could be too much challenging and could again jeopardize the whole project. New ERP systems are important part of any reform because of ensuring users' accessibility to accounting data necessary for better decision making. However, these sophisticated financial management tools could be expensive and their development time demanding. Comparing these four aspects in several European countries gives better insight and could confirm or disconfirm their importance.

\section{Comparative analysis}

As mentioned before, IPSAS standard have been chosen for a benchmark in this comparison. This comprehensive set of almost forty various standards covering in fact all the issues that occur in public sector companies, no matter which part of the globe is the country from. This specific quality - no domestic region where IPSAS standards arrived from is also the reason why they could fit into various public sectors with different boundaries and different borderline between public and private sector. IPSAS standards are intended to be applied into various jurisdictions with different organization of government and with variously organized public services provided (IFAC, 2014). Majority of the other systems are for domestic purposes, not intended to be applied abroad. Also in the Introduction part, there has been mentioned that IPSAS standards continually bear the idea of the accountability of the public sector organizations to the public services consumers and to providers of resources for these services. The concept of evaluation of the level and quality of the public services is visible and present through all the standards. The accrual basis is mentioned at the very face of IPSAS standards and they all keep this presumption as the basement of all the specific reporting rules. It is clearly said in the IPSAS Conceptual Framework that the economic information based on the accrual basis "provide information about past transactions and other events that is more useful to users for accountability purposes and as input for decision making than is information provided by the 
Svoboda, M.: $\quad$ Modernisation of Public Sector Financial Reporting Systems in Europe - Challenges and Milestones.

cash basis or other bases of accounting or financial reporting." (ibid.) It is not the aim of this paper to analyse, describe or judge IPSAS standards themselves, but this short description has been made to proof suitability of these standards as a benchmark for other comparison. They could possibly serve as benchmark fulfilling the requirements on reporting system covering the very substance of public sector - providing public services (public goods).

However, there could be several reasons for choosing or for not choosing IPSAS standards as a benchmark for or a criterion of success of a public sector financial reporting standards modernization projects. Brusca et al. (2016) offer four reasons focusing on Latin American countries: pressure and demand of international organizations as the International Monetary Fund or the World Bank, activities of "Big Four" companies aiming getting public sector accounting rules similar or same as private sector accounting rules, international prestige and rising number of successful implementation around the world. Oulasvirta (2013) summarizes the approach of Finnish central government who have been reluctant to implement IPSAS standards as a whole, but have recognized them to be a source of inspiration for Finnland. One of the reasons Oulasvirta (ibid.) mentioned is a problem of IPSAS standards with interconnection with budgetary rules and procedures specific for each country. Christiaens et al. (2012) noted the connection of IPSAS standards with the general New Public Management (NPM) approach. So there are obviously several viewpoints from where IPSAS standards could be seen as useful and clear direction for goal-setting of a public sector financial reporting system modernization project.

IPSAS standards very often stand for an example of a really full accrual based set of standards. The evolution and development of these standards was quite short. That was possible thanks to starting with International Financial Reporting Standards (IFRS) as a starting point, even though IFRS are for the private sector companies. Until today, these two sets of standards didn't diverge significantly, so we can consider IFRS as (almost) compatible with IPSAS. What's more, there are some countries around the world which use IFRS standards for the public sector entities. To present a comparison of public sector financial reporting systems in developed countries in the world, we can also use results of the OECD annual survey and other OECD database (OECD, 2015). 
European Financial and Accounting Journal, 2016, vol.11, no. 4, pp. 05-16.

Tab. 1: Accrual or cash basis in public sector financial reporting in Europe

\begin{tabular}{|c|c|c|c|c|c|}
\hline \multirow{2}{*}{ Country } & \multicolumn{2}{|c|}{ Full accrual } & \multirow{2}{*}{$\begin{array}{l}\text { Modified } \\
\text { accrual }\end{array}$} & \multirow{2}{*}{$\begin{array}{l}\text { Modified } \\
\text { cash }\end{array}$} & \multirow{2}{*}{ Full cash } \\
\hline & IPSAS/IFRS & Other & & & \\
\hline Austria & $X$ & & & & \\
\hline Belgium & & $X$ & & & \\
\hline $\begin{array}{l}\text { Czech } \\
\text { Republic }\end{array}$ & & $X$ & & & \\
\hline Denmark & & $\mathrm{X}$ & & & \\
\hline Estonia & $X$ & & & & \\
\hline Finland & & $X$ & & & \\
\hline France & & $\mathrm{X}$ & & & \\
\hline Germany & & & & & $\mathrm{X}$ \\
\hline Greece & & & & $\mathrm{X}$ & \\
\hline Hungary & & $X$ & & & \\
\hline Iceland & & & $\mathrm{X}$ & & \\
\hline Ireland & & & & $\mathrm{X}$ & \\
\hline Italy & & & & $\mathrm{X}$ & \\
\hline Latvia & $\mathrm{X}$ & & & & \\
\hline Lithuania & & $X$ & & & \\
\hline \multicolumn{6}{|l|}{ Luxembourg } \\
\hline Netherlands & & & & $\mathrm{X}$ & \\
\hline Poland & & $X$ & & & \\
\hline Portugal & & & & $X$ & \\
\hline Slovakia & & $\mathrm{X}$ & & & \\
\hline Slovenia & & & & & $X$ \\
\hline Spain & & $\mathrm{X}$ & & & \\
\hline Sweden & & $X$ & & & \\
\hline Switzerland & $X$ & & & & \\
\hline Turkey & & $X$ & & & \\
\hline $\begin{array}{l}\text { United } \\
\text { Kingdom }\end{array}$ & $\mathrm{X}$ & & & & \\
\hline TOTAL & 5 & 12 & 1 & 5 & 2 \\
\hline
\end{tabular}

Source: OECD (2015); authorial assessment. 
Svoboda, M.: $\quad$ Modernisation of Public Sector Financial Reporting Systems in Europe - Challenges and Milestones.

Tab. 1 shows current state in all the OECD countries in relative contrast with IPSAS/IFRS standards as a benchmark. Further comparison aims in more detail at some of the full accrual based countries, where according to available data, during last approximately twenty years some kind of financial reporting reform or modernization has been carried out. This concrete analysis will identify the four key aspects of these modernizations in those countries. Further comparison will use especially two data resources, the OECD database and official presentations (OECD, 2015) and a PwC study (PwC, 2014). Some specific additional source is added where needed to make some points clearer. This would be marked clearly. Subject of further comparison will be Austria, the Czech Republic, Denmark, Estonia, France, Sweden, Switzerland, United Kingdom. Countries are in alphabetic order.

In Austria, a rigorous reform was made since 2009 until 2013. The first step was to introduce a mid-term expenditure framework focusing on preliminary public expenditure controls and setting out an expenditure ceilings for several fields of central government responsibility. The second step was to introduce and implementation of fully linked accrual accounting with implementing IPSAS standards and accrual budgeting systems, ERP systems and performance budgeting. Still only central government entities are covered, local governments are offered to license the ICT infrastructure, acquire know-how and methodological support on a voluntary basis. Austrian financial reporting system could be marked as very advanced.

In the Czech Republic quite a broad financial reporting reform has been started in 2010 after three years' preparation period. All the public sector entities are involved, including all the local governments. Financial reporting rules are based on IPSAS standards, but are not equivalent. Until these days, no special ERP system has been developed as a direct consequence with this modernization effort. Almost all the projects have been carried out by internal staff.

Central government entities in Denmark implemented the accrual basis into their financial reporting systems between 2003 and 2005. Even a developed ERP system has been implemented too, not all the central government entities are involved. Local governments have not been involved at all. Accrual basis implemented does not mean the implementation of IPSAS standards.

Estonian central government and local government were having implemented IPSAS standards from their very creation and publication by IPSAS Board, approximately after 2010 . Estonian both central and local government are not very extensive in terms of number of accounting entities (less than 1400 entities). The implementation project development, realization and the implementation itself have been carried out by external experts. 
France has full accrual system similar with IPSAS standards since 2001 in legislation and since 2006 in place, but for the central government only. Also a rigorous ERP system have been developed and implemented. Currently French government has introduced an exposure draft on the French governmental accounting conceptual framework.

Modernization of public sector financial reporting in Sweden was more an evolution rather than a revolution. It was an issue of especially 1990's when all the central government entities started to prepare their financial statements under the accrual basis. No IPSAS standard existed already in that times. It was all a part of a broader fiscal modernization project. The key aim was to achieve a more relevant information system for a better decision making process in the central government. Also external experts have been involved, but the most of the workload have been done by civil servants.

Swiss confederation has implemented a complete set of IPSAS standards for central government as the very first state in the world in 2010. The project of implementation has been organized by external experts from both private companies and public universities. The project also meant a new ERP system, cost management and performance budgeting. Local governments have not been involved, but after the end of the implementation phase, they have been offered to implement the new system on a voluntary basis. Some of them did that.

As well as in Sweden, the modernization of public sector financial reporting in the United Kingdom has been rather an evolutionary process. It has started in 1993 and after 2010 whole-of-government financial statements are published on yearly basis. All the public sector entities use the International Financial Reporting Standards (IFRS) which is quite unique all around the world. These private sector set of standards is in fact a basis for development of IPSAS standards and in the most of areas both of these systems are equal. Both of them represent full accrual basis standards. In the very last years, stress is put on using of accounting data for a quality decision making of governments using also new ERP systems.

The table which follows summarizes key challenges and milestones they could be marked as "key aspects" of financial reporting system modernization projects in several European countries. It is the output of second level of the whole analysis. 
Svoboda, M.: $\quad$ Modernisation of Public Sector Financial Reporting Systems in Europe - Challenges and Milestones.

Tab. 2: Comparison of key aspects in public sector accounting reforms

\begin{tabular}{|c|c|c|c|c|c|c|c|c|}
\hline \multirow[t]{2}{*}{ Country } & \multicolumn{2}{|c|}{$\begin{array}{l}\text { Internal human } \\
\text { resources }\end{array}$} & \multicolumn{2}{|c|}{$\begin{array}{c}\text { Local } \\
\text { government } \\
\text { included }\end{array}$} & \multicolumn{2}{|c|}{$\begin{array}{l}\text { IPSAS standards } \\
\text { implemented }\end{array}$} & \multicolumn{2}{|c|}{$\begin{array}{c}\text { New ERP } \\
\text { implemented }\end{array}$} \\
\hline & Yes & No & Yes & No & Yes & No & Yes & No \\
\hline Austria & $X$ & & & $X$ & $X$ & & $X$ & \\
\hline $\begin{array}{l}\text { Czech } \\
\text { Republic }\end{array}$ & $X$ & & $X$ & & & $X$ & & $\mathrm{X}$ \\
\hline Denmark & $X$ & & & $X$ & & $X$ & $X$ & \\
\hline Estonia & & $X$ & $X$ & & $X$ & & & $X$ \\
\hline France & $\mathrm{X}$ & & & $\mathrm{X}$ & & $\mathrm{X}$ & $X$ & \\
\hline Sweden & $X$ & & & $\mathrm{X}$ & & $X$ & & $X$ \\
\hline Switzerland & & $X$ & & $\mathrm{X}$ & $\mathrm{X}$ & & $X$ & \\
\hline $\begin{array}{l}\text { United } \\
\text { Kingdom }\end{array}$ & $X$ & & $X$ & & $\mathrm{X}$ & & $\mathrm{X}$ & \\
\hline TOTAL & 6 & 2 & 3 & 5 & 4 & 4 & 5 & 3 \\
\hline
\end{tabular}

Source: OECD, 2015; PwC, 2014; Svoboda, 2013; authorial assessment.

\section{Discussion and conclusion}

Several European countries have carried out more or less extensive public sector financial reporting system modernization projects during last two decades. Central governments try to be accountable to the citizens and aim to provide them with more relevant, comprehensive and reliable financial information. The effort of governments is to offer to the taxpayers some value for money and to offer adequate quality and range of public goods (public services). A modern public sector financial reporting system is the key source of data necessary for an assessment of such an effort. It is necessary tool for government's accountability in developing countries just as in developed countries in Europe. Governments in Europe are well aware of the existence of IPSAS standards and aim either to implement them or to make them a guidance for their own public sector accounting standards development. Many developed countries in Europe consider IPSAS standards as the best way how to achieve accountability and try to implement them to a certain extent into their own modernization projects. There is then the question, whether this goal could be a threat for the success of the whole project, because it could be too complex and too complicated to implement even full accrual standards, let alone implement IPSAS/IFRS. Next question could be whether there are some other aspects they should be decided by the project management at its very beginning and could threaten the success of the whole project when decided wrong. 
Comparative analysis in this paper, exactly its first level shows that in 17 of 25 examined European countries a decision on the full accrual basis for the public sector financial reporting has been made. To enhance their accountability, they decided either to implement IPSAS/IFRS standards or to implement/modernize their own national standards into a full accrual basis more or less similar to IPSAS/IFRS. As any modernization project in any field, also these particular projects were not easy to successfully finish. Published and available sources show at least four key aspects (key questions) that have been to decide by the government at the beginning of their modernization projects: Using external or internal human resources, covering not only the central government, but also local governments, development of a brand new ERP systems and, of course, decision on implementation of IPSAS/IFRS. These four aspects have been a subject of the second level of the analysis. They have been compared using a sample of 8 from 17 examined European countries where some kind of financial reporting reform have been carried out with the outcome of full accrual basis or IPSAS/IFRS implemented.

The output from the second level of an analysis is the main finding of this paper. It shows that in 6 from 8 countries internal experts (civil servants) have been the key personnel in project management and/or in all the specific financial reporting issues. Necessity of external consultants hasn't been confirmed. We can also see that in 5 from 8 countries local governments were not an obligatory part of the whole projects, however, in some of that countries could decide on a voluntary basis. The enforcement of a new financial reporting system within the central government only is probably much easier. In 4 from 8 countries IPSAS/IFRS standards have been the goal of the project, in the rest four countries a full accrual basis has been sufficient enough. There is then no definite conclusion on this factor. In 5 from 8 countries, brand new ERP system has been developed to strengthen users' abilities of employment of the accounting data. We can than conclude that aiming at modernization of public sector financial reporting systems, in house staff, concentration on central government and parallel development of new ERP systems are rather recommended approaches. 
Svoboda, M.: $\quad$ Modernisation of Public Sector Financial Reporting Systems in Europe - Challenges and Milestones.

\section{References}

Brusca, I., Gómez-Villegas, M., Montesinos, V, 2016. Public Financial Management Reforms: The Role of Ipsas in Latin-America. Public Administation and Development 36, 51-64. DOI: 10.1002/pad.1747.

Christiaens, J., Rommel, J., Barton, A., Everaert, P., 2012. Should all capital goods of governments be recognised as assets in financial accounting? Baltic Journal of Management 4, 429-443. DOI: 10.1108/17465261211272175.

International Federation of Accountants (IFAC), 2014. Handbook of International Public Sector Accounting Pronouncements I. New York.

Musgrave, R. A., Musgrave, P. B., 1994. Veřejné finance v teorii a praxi. Praha, Management Press.

Niskanen, W. A., 1996. Bureaucracy and public economics. Repr. Edward Elgar, Cheltenham, John Locke series.

Organisation for Economic Co-operation and Development (OECD), 2015. The OECD Accruals Survey. Paris, France. Available from: <http://fr.slideshare.net/ OECD-GOV/tag/sbo-accruals-february-2015>. [11 December 2015].

Oulasvirta, L., 2013. The reluctance of a developed country to choose International Public Sector Accounting Standards of the IFAC. A critical case study, Critical Perspectives on Accounting 1, 1-14.

PwC, 2014. Collection of information related to the potential impact, including costs, of implementing accrual accounting in the public sector and technical analysis of the suitability of individual IPSAS standards 2013/S 107-182395. PricewaterhouseCoopers, Brussels, Belgium. Available from: <http://www. pwc.com/gx/en/psrc/pdf/pwc-implementing-epsas.pdf>. [11 December 2015].

Schumesch, P., De Greef, A., De Laet, J., 2015. IPSAS in a nutshell. From principles to practice. Brussels, Belgium, PwC.

Stiglitz, J. E., 2000. Economics of the public sector. New York, W.W. Norton.

Svoboda, M., 2013. Reforma účetnictví státu jako předpoklad ekonomického rozhodování externích uživatelů účetních výkazů obcí. Dissertation thesis. University of economics in Prague. Faculty of Finance and Accounting. Supervisor: Ladislav Mejzlík. 